\title{
Marketing Positions of Kremenchuk Industrial Center in International Markets
}

\author{
Oleh Kratt ${ }^{1}$, Andryi Pochtovyuk ${ }^{1}$, Iryna Trunina ${ }^{1}$, Kateryna Pryakhina ${ }^{1 *}$ \\ ${ }^{1}$ Kremenchuk Mykhailo Ostrohradskyi National University, Ukraine
}

\begin{abstract}
In the article, the authors analyze the role of Kremenchuk as an industrial center. It is determined that Kremenchuk is represented by such flagships machine building enterprises as PJSC "Kryukiv Rail Car Plant", PJSC “AvtoKrAZ”, PJSC "Kredmash", PJSC "Kremenchuk Wheel Plant", PJSC "Kremenchuk Steel Works". Therefore, the author proposes to carry out the marketing positioning of the Kremenchuk industrial center on the international market, which includes powerful enterprises. The financial economic and marketing activity of machine-building enterprises members of the Kremenchuk industrial center is analyzed. Through the dialectical connection of methods of analogy and deduction, the stages of development of marketing positioning for the center are proposed for expanding international sales markets for enterprises, marketing positioning is realized by developing a set of marketing tools. It is determined that the effective positioning of the Kremenchuk industrial center will lead to the formation of the brand.
\end{abstract}

\section{Introduction}

The competitiveness of the Ukrainian machine building complex at the international level is formed of competitiveness of a complex of regions. So, regions operate on the basis of the efficiency of economic entities operating in their territory. Machine building industry creating the most active part of the main production assets, significantly influences the pace and direction of scientific and technological progress, the growth of labor productivity and other economic indicators. The deterioration of fixed assets of the existing industrial enterprises, lack of working capital and their limited ability to attract investments to upgrade the existing equipment and to introduce innovative products create a threat to the preservation and increase of the competitiveness of the regional economy as a whole [1].

Therefore, the mission of the industrial center is to be the leader and instrument of realization of sustainable economic development of the region by its effective marketing positioning.

Kremenchuk is a Ukrainian city of regional subordination, an administrative and industrial center and has always been positioned as a major industrial center in the Poltava region. As there are 86 powerful industrial enterprises in the city, among which there are oil refining, chemical, machine-building, metallurgical, metalworking, food, light, and construction industries [2]. About 75 enterprises (86\% of total number) export industrial

${ }^{*}$ Corresponding author: katerinapryakhina@gmail.com 
goods [3]. It should be noted that the uniqueness of the center lies in its machine-building orientation, as evidenced by the presence of such flagships of the Ukrainian machine building, which are well known abroad as PJSC "Kryukiv Rail Car Plant", PJSC "AvtoKrAZ", PJSC "Kredmash", PJSC "Kremenchuk Wheel Plant", PJSC "Kremenchuk Steel Works". That is, Kremenchuk as an industrial center has competitive advantages in international markets; however, according to the data of the Main Department of Statistics in the Poltava region, the foreign trade in goods and services of Kremenchuk in recent years has been characterized by negative growth. Therefore, the question of developing a unified marketing positioning of the center for these machinebuilding enterprises arises. The choice of a single strategy is possible taking into account the specific features of enterprises within a single industry, and using the method of analogy to formulate a strategy of marketing positioning of one enterprise, it is possible to generalize it to the center as a whole.

\section{Data and Methods}

Indicators of the Ukrainian for Enterprise and Stock Market Infrastructure Development Agency (SMIDA) were used for the analysis.

The study has selected absolute indicators that characterize the financial and economic activities of the companies - "net revenue from sales of products (goods and services)" and marked with a symbol $W_{i}$; "net financial profit" marked with a symbol $P_{i}$ and "net financial loss" is indicated $-P_{i}$. The indicator of the rate of increase $\left(T_{p}^{l}\right)$ was chosen to justify the assessment of changes in the performance of enterprises. For analysis, such synthetic indicators are used: $T_{p}^{l} W$ - "rate of increase of net revenue from sales over the period", $T_{p} P$, - "rate of increase the net financial profit", where $i$ is section of the studied period (calendar year), value of $i$ is reduced to the last two digits of the year, so $i=\{16,17\}$.

Taking into account the similar financial instability of enterprises and identifying common risks at the exit and expansion of foreign markets, the creation of a unified marketing positioning of Kremenchug industrial center in the international market is proposed using analog and deduction methods (Fig. 1).

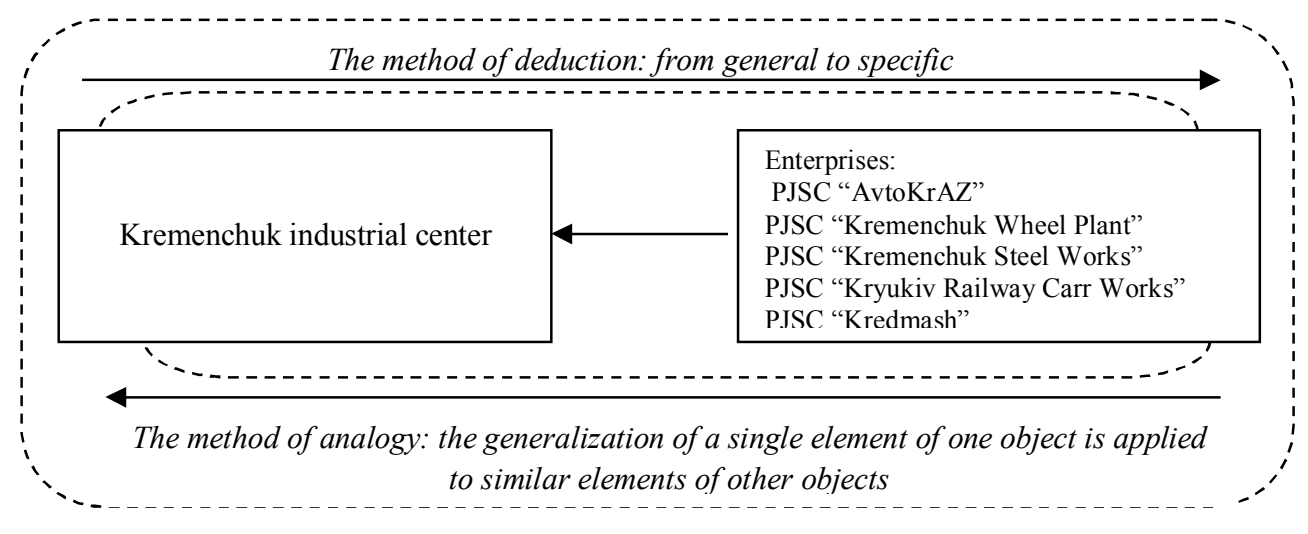

*author's development

Fig. 2. Sales to international markets (share, \%).

Analogy is a method of scientific research, in which from the similarity of objects of the class in one of the features a conclusion is made about their similarity in other features. The essence of the analogy can be expressed using the formula: A has signs abcd, B has signs abc, so, B, apparently, has the sign $\mathrm{d}$. The method of analogy gives the most valuable 
results when an organic relationship is established not only between such signs, but also with the signs that is transferred to the object under investigation [4]. In this research, the method is in inseparable dialectic connection with the deduction

According to Fig. 1, the method of analogy with the financial and marketing activities of enterprises allowed to generalize the marketing positioning for the Kremenchuk industrial center. In the future, the method of deduction will allow to develop measures in general for the center and which will be universal for each enterprise individually [5].

\section{Results}

\subsection{Financial activity of enterprises-members of the Kremenchuk industrial center}

To determine the main directions of the marketing positioning of the Kremenchuk Center, it is necessary to consider the main financial indicators of the abovementioned enterprises (see Table 1).

Table 1. The analysis of indicators of financial and economic activity of enterprises.

\begin{tabular}{|l|c|c|c|c|c|c|}
\hline \multirow{2}{*}{ Enterprise / Indicators } & \multicolumn{3}{|c|}{$W_{i}, \mathrm{UAH}$} & \multicolumn{3}{c|}{$P_{i} /-P_{i}, \mathrm{UAH}$} \\
\cline { 2 - 7 } & 2016 & 2017 & $T_{p}^{l} W, \%$ & 2016 & 2017 & $T_{p}^{l} P, \%$ \\
\hline $\begin{array}{l}\text { PJSC “Kryukiv Rail Car } \\
\text { Plant" }\end{array}$ & $2,150,001$ & $3,847,179$ & 44.11 & $-11,2848$ & 331,983 & - \\
\hline PJSC “AvtoKrAZ" & $1,231,793$ & $1,047,864$ & -17.55 & $-19,1815$ & $-89,728$ & $(113.77)$ \\
\hline PJSC “Kredmash" & 513,613 & 894,583 & 42.58 & 51,434 & 95,769 & 46.29 \\
\hline $\begin{array}{l}\text { PJSC “Kremenchuk } \\
\text { Wheel Plant” }\end{array}$ & 526,217 & 687,392 & 23.44 & 26,473 & 21,951 & 20.60 \\
\hline $\begin{array}{l}\text { PJSC “Kremenchuk Steel } \\
\text { Works" }\end{array}$ & 297,250 & 710,920 & 58.19 & 32,132 & $-9,673$ & - \\
\hline
\end{tabular}

* author's development on the basis of [6]

According to Table 1, it should be noted that PJSC "Kryukiv Rail Car Plant", PJSC "Kredmash" and PJSC "Kremenchuk Wheel Plant" according to the results of 2017, earned profit 331,983 UAH, UAH 95,769 and UAH 21,951, respectively. In this case, the activity of PJSC "AvtoKrAZ" and PJSC "Steelmaking Works" was unprofitable.

The value of the indicator $W_{17}$ of PJSC "Kryukiv Rail Car Plant" was 3,847,179 UAH, which indicates an increase the revenue for $44.11 \%$. The value of the indicator $-P_{16}$ was $-112,848 \mathrm{UAH}$, and $P_{i}$ was UAH 33,183, it means that enterprise got the profit in 2017. "Kredmash", during the reporting period, increases revenues and profits, as evidenced by the value of the indicator $T_{p}^{l} W=42.58 \%$ and $T_{p}^{l} P=46.29 \%$. Similarly tendency was at "Kremenchuk Wheel Plant", but its value is somewhat lower than that of Kredmash and was $T_{p}^{l} W=23.44 \%$ and $T_{p}^{l} P=20.60 \%$.

As was noted during the 2016-2017 period, PJSC “AvtoKrAZ" worked with loss, but it decreased by $13 \%$ in 2017 . At the same time the revenue decreased and the value of $T_{p} W=-17.55 \%$. Despite the fact that the "Kremenchuk Steel Works" in 2017 compared to 2016 revenue increased and value of $T_{p}^{l} W$ was $58.19 \%$, received a loss of 9673 UAH. Thouse, the analysis of indicators of Kremenchuk enterprises showed instability as the enterprises had a loss or insignificant revenue during the reporting period. 


\subsection{Activity of the members of Kremenchuk industrial center in foreign markets and marketing tasks}

However, the activity of enterprises in the international arena and foreign markets should be analyzed for further research (Fig. 2).

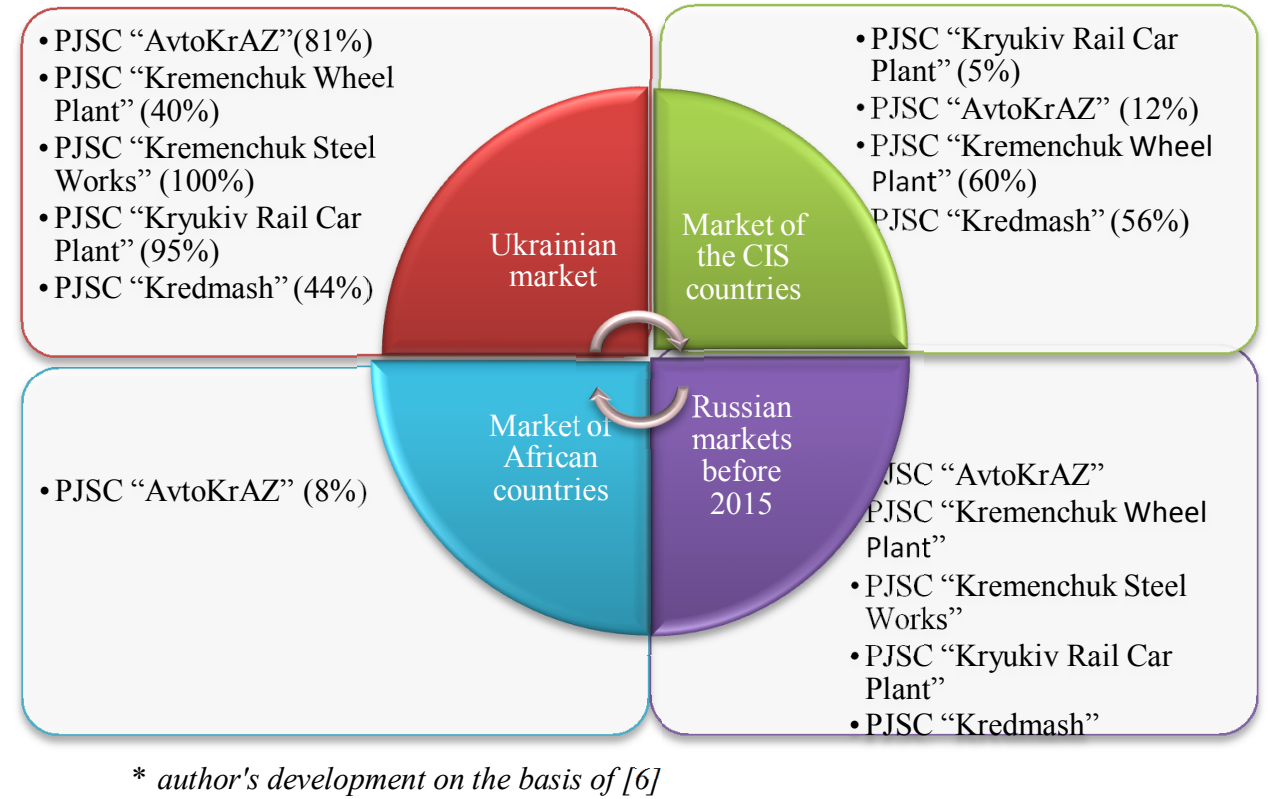

Fig. 2. Sales to international markets (share, \%).

In recent years, PJSC "Kremenchuk Steel Works" has not been present at international markets at all, being oriented only to the Ukrainian one, since the enterprise was previously working in the Russian market. The main consumers are car production and car repair enterprises. Products are sold on a contractual basis both to private enterprises, as well as to the public ones according to the procedure of trades on the Prozorro electronic platform. The marketing department is actively working towards creating an image of a trusted company, defining the goals and strategies of market activity on the domestic and foreign markets. The main risks affecting the activity of the issuer are the influence of the political situation in the state on the development of rail transport and the associated unstable demand for the carriage industry in the country. Also, the risks may include the possible expansion of foreign manufacturers; in particular Chinese with dumping prices for similar products, but with an uncertain level of quality and obscure warranty obligations. The methods of protecting their activities include the development of programs for the protection of domestic producers.

A similar situation has arisen at PJSC "AvtoKrAZ" regarding the impossibility of delivering products to the Russian market. The Russian market for a long period of time was the key to PJSC “AvtoKrAZ": by 2013, supplies to Russia accounted for more than $50 \%$ of the annual total sales volume of PJSC "AvtoKrAZ" products. During the last three years, supplies to the domestic market have increased significantly, deliveries have been made both to traditional foreign partners and to new consumer countries. The risks of company are the growth of exchange rates as the consequence is to increase the cost of finished products and reduce the profit from its realization. For example, in 2017, the growth of exchange rates caused a rise in materials by $31 \%$, component parts - by $16 \%$. To overcome this situation, the company applies a flexible pricing policy in order to maximize 
its position on a specific market. Further impossibility of deliveries of products to the Russian market through the inter-state conflict led to the loss of a large market of sales. Therefore, sales departments have intensified their efforts to find new international sales markets.

The main obstacles in entering the international markets of PJSC "Kryukiv Carriage Works" are as follows: the absence of real foreign investors, the lack of an effective mechanism for the promotion of Ukrainian products at the state level and lobbying the interests of domestic commodity producers in foreign markets, in the free trade zone between Ukraine and the EU. The main production risks are the transition of Ukrainian manufacturers to EU standards. At the same time, the enterprise continuously implements quality management systems of the international standard, integrates resources for the development of high-tech system engineering projects.

The main risks of in PJSC "Kremenchuk Wheel Plant" are the political aspects - the possibility of increasing taxes, problems with the customs clearance of goods, and the economic - related to changes in the exchange rate, which can lead to unplanned losses. The main direction of the company's marketing policy is to obtain maximum profit, achieve maximum customer satisfaction, and increase the competitiveness of products.

PJSC "Kredmash" is focused on expansion of markets at the expense of the Middle East, Africa, and Southeastern Asia. The risks that may affect the financial and business activities of PJSC "Kredmash" are political instability, recession, lowering the pace of economic development, inflation growth, the procedure for certification of products in importing countries, the development of new technologies and the orientation of consumers for technical innovation of a certain nature, a high degree of dependence of production on the supply of components and materials.

Thus, all of these enterprises lost a large Russian market of sales. Taking into account the political conflict and economic situation, marketing departments point out the need for reorientation and are constantly looking for new international markets. There are also the same risks for all enterprises: political instability, exchange rate change, lack of investment, reorientation and technical standards of the EU, etc. Taking into account the common challenges and problems of enterprises, this indicates the need to combine efforts to create a positive image of companies through marketing positioning as the only Kremenchuk industrial center.

\subsection{Marketing positioning of the Kremenchuk industrial center}

Today, the attitude of heads of domestic enterprises to unions in the centers has changed. They are considered as a tool for further development, a prerequisite for the introduction of business in a context of increased competition between national enterprises and between Ukrainian and foreign companies. The formation of such centers of the enterprise prompts a number of prerequisites of internal and external nature. In particular, the most important external prerequisites are general economic ones.

Marketing positioning is a complex of measures, which, in the consciousness of the target buyers, this product is relatively intrinsically comparable to other competing goods and a favorable place [7]. For effective positioning, the use of all components of the marketing mix is important, but promotion activities are one of the main roles, as they are the mechanism for reporting positioning to the target audience [8]. Significant moments of this issue are constant positioning and consistency in advancement. So, PR and advertising programs should be linear rather than spatial. In a spatial program, all its elements start simultaneously, but in different places. In the linear program, the elements, revealing for a certain time, have the ability to interact, reinforcing each other. In the formation of a stable position, a significant role is played by all elements of the promotion of the mix: ATL and 
BTL instruments, in particular, merchandising plays an important role. In the final analysis, positioning should lead to the formation of the brand.

Taking into account the above mentioned risks, obstacles and problems of the enterprises, it is possible to propose the following algorithm of the market positioning of enterprises and the center as a whole on the international markets:

analyze competitors and evaluate their positioning;

analyze the product and compare it with the positioning of the product of competitors;

analyze the target audience;

determine the current position of enterprises;

create maps of desirable states and positions of enterprises;

develop positioning and implement it;

evaluate the effectiveness of the introduced positioning and will promote the "brand" of the center in the future.

Effective marketing positioning of machine-building enterprises will allow the Kremenchuk industrial center to create the image that will promote the attraction of investors and socio-economic development of the city as a whole and will further enable the development of marketing positioning from the standpoint of branding.

\section{References}

1. Buzko, O. Vartanova, I. Trunina, \& I. Khovrak, SHS Web of Conferences. Innovative Economic Symposium 2018 Milestones and Trends of World Economy (IES2018), 61, 01001, (2019).

2. Official website of "Kremenchuk City Council and Executive Committee". [online]. Available at: https://www.kremen.gov.ua/?view=main.

3. The State Statistics Service of Ukraine [online]. Available at: www.ukrstat.gov.ua/

4. A. Uemov, Analogy in the practice of scientific research: From the history of physical and mathematical sciences. Nauka Publishing House, 258. (1970).

5. K. Pryakhina, Effective economy: electronic scientific professional edition. Dniprovsky Agrarian and Economic University, 4 (2018). [online]. Available at: http://www.economy.nayka.com.ua/pdf/4 2018/153.pdf

6. Official site "Agency for the development of the infrastructure of the stock market of Ukraine" [online]. Available at: https://smida.gov.ua/.

7. N. Kudenko, Formation of a Market Economy: Coll. sciences works "Marketing: Theory and Practice". 1, 393-403. (2007).

8. O. Maslak, P. Sokurenko, N. Grishko, M. Maslak, SHS Web of Conferences. Innovative Economic Symposium 2018 Milestones and Trends of World Economy (IES2018), 61, 01014. (2019). 